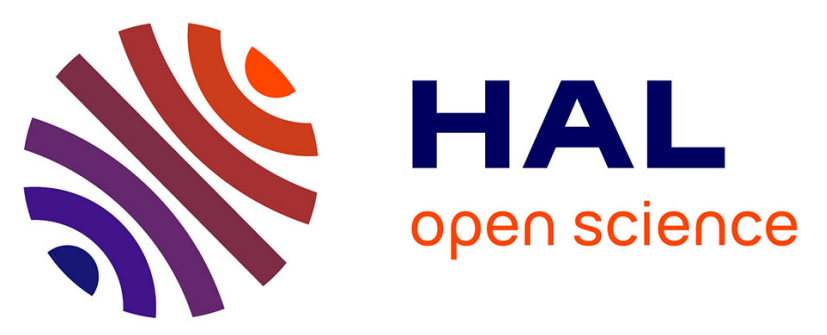

\title{
Evaluation of Turkish melon accessions for resistance to Fusarium wilt, downy mildew, powdery mildew, Cucumber mosaic virus and Zucchini yellow mosaic virus
} Ilkour Solmaz, N. Sari, Catherine Dogimont, Michel Pitrat

\section{- To cite this version:}

Ilkour Solmaz, N. Sari, Catherine Dogimont, Michel Pitrat. Evaluation of Turkish melon accessions for resistance to Fusarium wilt, downy mildew, powdery mildew, Cucumber mosaic virus and Zucchini yellow mosaic virus. 29. International Horticultural Congress on Horticulture - Sustaining Lives, Livelihoods and Landscapes (IHC) / International Symposium on Plant Breeding in Horticulture, Aug 2014, Brisbane, Australia. Acta Horticulturae, 1127, 2016, Acta Horticulturae. 10.17660/ActaHortic.2016.1127.22 . hal-01604952

\section{HAL Id: hal-01604952 \\ https://hal.science/hal-01604952}

Submitted on 2 Jun 2020

HAL is a multi-disciplinary open access archive for the deposit and dissemination of scientific research documents, whether they are published or not. The documents may come from teaching and research institutions in France or abroad, or from public or private research centers.
L'archive ouverte pluridisciplinaire $\mathbf{H A L}$, est destinée au dépôt et à la diffusion de documents scientifiques de niveau recherche, publiés ou non, émanant des établissements d'enseignement et de recherche français ou étrangers, des laboratoires publics ou privés. 


\title{
Evaluation of Turkish melon accessions for resistance to Fusarium wilt, downy mildew, powdery mildew, Cucumber mosaic virus and Zucchini yellow mosaic virus
}

\author{
I. Solmaz ${ }^{1, a}$, N. Sari ${ }^{1}$, C. Dogimont ${ }^{2}$ and M. Pitrat ${ }^{2}$ \\ ${ }^{1}$ Cukurova University, Faculty of Agriculture, Department of Horticulture, 01330, Adana, Turkey; 2INRA, \\ Génétique et Amélioration des Fruits et Légumes, Domaine St Maurice - Allée des Chênes, CS 60094, 84143 \\ Montfavet Cedex, France.
}

\begin{abstract}
The aim of this study was to detect disease resistance in melon genetic resources collected from different regions (south-eastern Anatolia, middle Anatolia, Aegean, Marmara-Thrace and eastern Anatolia) of Turkey. A total of 85 melon and 15 snake melon genotypes were tested against Fusarium wilt (races 1 and 2), downy mildew and powdery mildew (race 3 ) as fungal diseases, and Cucumber mosaic virus (CMV) and Zucchini yellow mosaic virus (ZYMV) as virus diseases. In the case of Fusarium wilt race 1, eight genotypes were found resistant, 86 genotypes were susceptible and one genotype was segregating. Fifty-four percent of the genotypes were found to be resistant, $28 \%$ were susceptible and $18 \%$ were segregating for Fusarium wilt race 2 . In the case of downy mildew, four genotypes ('Kav 28', 'Kav 71', 'Kav 237' and 'Kav $255^{\prime}$ ) were resistant, while 78 genotypes were susceptible and 16 genotypes were segregating. Among all the genotypes tested, only two genotypes ('Kav 60 ' and 'Kav 277') were resistant to powdery mildew. While two genotypes ('Kav 281' and 'Ac 33') were found to be resistant to CMV, none of the genotypes were resistant to ZYMV.
\end{abstract}

Keywords: Cucumis melo, fungal diseases, virus, artificial inoculation

\section{INTRODUCTION}

Turkey is a rich country in terms of plant genetic resources, having about 163 families, 1225 genera and 9000 species in the flora, of which 3000 are endemic to Turkey. Therefore, the conservation and use of genetic material has a particular importance for Turkey (Özgen et al., 2000).

Melon (Cucumis melo L.) is a member of the family Cucurbitaceae and has a high level of morphological diversity (Kirkbride, 1993; Whitaker and Davis, 1962; Pitrat et al., 2000). Commercial production in Turkey is approximately 1.7 million tons (FAO, 2012), and the country is located in the secondary genetic diversity centre for melon (Pitrat et al., 2000). It has been reported that Turkey is rich in melon genetic resources, which are morphologically diverse, especially for fruit characters. Cukurova University Department of Horticulture has a melon genetic resources collection comprising more than 400 accessions, collected from different regions of Turkey and obtained from various countries in the world. Several studies have been conducted on morphological characterization of this melon germplasm (Solmaz et al., 2004; Sari and Solmaz, 2007). However, resistance to diseases and pests has not yet been investigated.

Diseases and pests are among the most important factors limiting melon production in Turkey. Fusarium wilt (Yucel et al., 1994), downy mildew (Koc, 1986), powdery mildew, Zucchini yellow mosaic virus (ZYMV) and Cucumber mosaic virus (CMV) (Yilmaz and Davis, 1984, 1985) cause significant problems in different melon-growing regions (Sari et al.,

${ }^{\mathrm{a} E}$-mail: isolmaz@cu.edu.tr 
1994).

Fusarium wilt (Fusarium oxysporum f.sp. melonis) is a soil-borne fungal disease and one of the main problems in melon. In Turkey, the pathogen is already widespread in the Aegean, Mediterranean, eastern and south-eastern Anatolia regions and threatens production in all other areas (Zengin et al., 1975; Yildiz, 1977; Yucel et al., 1994; Kinay et al., 1995; Demir and Tezcan, 1995; Maden et al., 1998; Erzurum et al., 1999; Baran, 2000; Kurt et al., 2002). Use of resistant cultivars was found to be more effective in combination with chemical protection (Scherf and Mancab, 1986; Martyn and Gordon, 1996). Downy mildew (Pseudoperonospora cubensis) is another fungal disease causing problems in melon production areas (Lebeda et Cohen, 2011). P. cubensis isolates collected in various areas of Turkey were recently shown to exhibit weak genetic diversity but to be strongly distinct from Israeli isolates (Polat et al., 2014). In melon plants, the symptoms begin with necrotic lesions on old leaves, then spread to the whole plant and cause death. Powdery mildew is one of the first identified diseases, and Podosphaera xanthii and Golovinomyces cichoracearum are the main causal agents. CMV and ZYMV are serious virus diseases widely distributed in melon-growing areas of Turkey.

The aim of this study was to evaluate the resistance of Turkish melon accessions to Fusarium wilt, downy mildew, powdery mildew, CMV and ZYMV.

\section{MATERIALS AND METHODS}

A total of 85 melon and 15 snake melon accessions was selected from the Cukurova University Department of Horticulture melon genetic resources collection and used as plant material. The origins and local names of the accessions are presented in Table 1.

Table 1. The origin, name and resistance of Turkish melon and snake melon accessions to Fusarium wilt, downy mildew, powdery mildew, CMV and ZYMV.

\begin{tabular}{|c|c|c|c|c|c|c|c|}
\hline Genotype & Origin & Local name & $\begin{array}{c}\text { Fusarium } \\
\text { race } 1\end{array}$ & $\begin{array}{c}\text { Fusarium } \\
\text { race } 2\end{array}$ & $\begin{array}{l}\text { Downy } \\
\text { mildew }\end{array}$ & $\begin{array}{c}\text { Powdery } \\
\text { mildew }\end{array}$ & CMV \\
\hline Kav 1 & Diyarbakir & Asma kavunu & $S$ & $S$ & $S$ & $S$ & $S$ \\
\hline Kav 3 & Mardin & Unknown & S & $\mathrm{R}$ & $\mathrm{H}$ & S & S \\
\hline Kav 5 & Sanliurfa & Unknown & S & $\mathrm{R}$ & S & S & S \\
\hline Kav 8 & Sanliurfa & Unknown & S & $S$ & S & S & S \\
\hline Kav 9 & Gaziantep & Unknown & S & $\mathrm{R}$ & S & S & S \\
\hline Kav 14 & Sanliurfa & Unknown & S & $\mathrm{R}$ & S & S & S \\
\hline Kav 19 & Gaziantep & Unknown & $S$ & S & $S$ & $S$ & $S$ \\
\hline Kav 23 & NCTR & Yerli & $S$ & $S$ & $S$ & $S$ & $S$ \\
\hline Kav 26 & Manisa & Kislik & $S$ & $\mathrm{H}$ & $S$ & $S$ & $S$ \\
\hline Kav 27 & Kutahya & Gonen & $S$ & $S$ & $S$ & $S$ & $S$ \\
\hline Kav 28 & Manisa & Melemen & - & - & $\mathrm{R}$ & $S$ & $S$ \\
\hline Kav 29 & Manisa & Cengel Tatar & $\mathrm{R}$ & $\mathrm{R}$ & $S$ & $S$ & $S$ \\
\hline Kav 30 & Konya & Cumra & S & $S$ & $S$ & $S$ & $S$ \\
\hline Kav 33 & Konya & Unknown & $S$ & $\mathrm{H}$ & $S$ & $S$ & $S$ \\
\hline Kav 34 & Konya & Unknown & $S$ & $\mathrm{R}$ & $\mathrm{H}$ & $S$ & $S$ \\
\hline Kav 36 & Usak & Unknown & $\mathrm{R}$ & $\mathrm{R}$ & $S$ & $S$ & $S$ \\
\hline Kav 37 & Istanbul & Unknown & $S$ & $S$ & $\mathrm{H}$ & $S$ & $S$ \\
\hline Kav 38 & Manisa & Dilim & $S$ & $\mathrm{H}$ & $S$ & $S$ & $S$ \\
\hline Kav 39 & Manisa & Lambada & $S$ & $S$ & $\mathrm{H}$ & $S$ & $S$ \\
\hline Kav 40 & Manisa & Dilim & $S$ & $\mathrm{R}$ & $\mathrm{H}$ & $S$ & $S$ \\
\hline Kav 42 & Tekirdag & Unknown & $S$ & $S$ & $S$ & $S$ & $S$ \\
\hline Kav 43 & Tekirdaq & Unknown & $S$ & $\mathrm{R}$ & $\mathrm{H}$ & $S$ & $S$ \\
\hline Kav 44 & Tekirdaq & Unknown & $S$ & $S$ & $\mathrm{H}$ & S & $S$ \\
\hline
\end{tabular}


Table 1. Continued.

\begin{tabular}{|c|c|c|c|c|c|c|c|}
\hline Genotype & Origin & Local name & $\begin{array}{l}\text { Fusarium } \\
\text { race } 1\end{array}$ & $\begin{array}{c}\text { Fusarium } \\
\text { race } 2\end{array}$ & $\begin{array}{l}\text { Downy } \\
\text { mildew }\end{array}$ & $\begin{array}{l}\text { Powdery } \\
\text { mildew }\end{array}$ & CMV \\
\hline Kav 45 & Tekirdag & Suluklu & $S$ & $\mathrm{H}$ & $S$ & $S$ & $S$ \\
\hline Kav 46 & Usak & Unknown & S & $\mathrm{R}$ & $S$ & $S$ & $S$ \\
\hline Kav 48 & Usak & Unknown & $S$ & $\mathrm{R}$ & $S$ & $S$ & $S$ \\
\hline Kav 50 & Manisa & Cavdan & $S$ & $\mathrm{R}$ & $S$ & $S$ & $S$ \\
\hline Kav 52 & Balıkesir & Acur & $S$ & $\mathrm{R}$ & $S$ & S & $S$ \\
\hline Kav 53 & - & Unknown & $S$ & $\mathrm{H}$ & $S$ & $S$ & $S$ \\
\hline Kav 54 & Manisa & Siyah & $S$ & $S$ & $S$ & $S$ & $S$ \\
\hline Kav 56 & Canakkale & Unknown & $S$ & $\mathrm{R}$ & - & - & $S$ \\
\hline Kav 57 & Adana & Unknown & $\mathrm{R}$ & $S$ & $\mathrm{H}$ & $S$ & $S$ \\
\hline Kav 59 & - & Girnogi & $S$ & $\mathrm{H}$ & $S$ & $S$ & $S$ \\
\hline Kav 60 & NCTR & Yerli & $S$ & $S$ & $\mathrm{H}$ & $\mathrm{R}$ & $S$ \\
\hline Kav 61 & Adiyaman & Bal & $S$ & $S$ & $S$ & $S$ & $S$ \\
\hline Kav 62 & Adiyaman & Kelek bal & $S$ & $\mathrm{R}$ & $S$ & $S$ & $S$ \\
\hline Kav 63 & Sanliurfa & Unknown & $S$ & $S$ & $S$ & $S$ & - \\
\hline Kav 64 & Mardin & Semamok & $S$ & $\mathrm{R}$ & $S$ & $S$ & $S$ \\
\hline Kav 65 & Sanliurfa & Selengo & $S$ & $\mathrm{R}$ & $S$ & $S$ & $S$ \\
\hline Kav 66 & Sanliurfa & Yabani & $S$ & $S$ & $S$ & $S$ & $S$ \\
\hline Kav 67 & Ankara & Unknown & $S$ & $S$ & $S$ & $S$ & $S$ \\
\hline Kav 70 & - & Kuscular & $S$ & $\mathrm{R}$ & $S$ & $S$ & $S$ \\
\hline Kav 71 & - & Unknown & $\mathrm{R}$ & $S$ & $\mathrm{R}$ & $S$ & - \\
\hline Kav 72 & Sakarya & Unknown & $S$ & $\mathrm{H}$ & $\mathrm{H}$ & $S$ & $S$ \\
\hline Kav 73 & Sanliurfa & Unknown & $S$ & $\mathrm{R}$ & $S$ & $S$ & $S$ \\
\hline Kav 74 & Sanliurfa & Unknown & $S$ & $S$ & $\mathrm{H}$ & $S$ & $S$ \\
\hline Kav 79 & Ankara & Unknown & $S$ & $S$ & $\mathrm{H}$ & $S$ & $S$ \\
\hline Kav 82 & Usak & Unknown & $S$ & $\mathrm{R}$ & $\mathrm{H}$ & $S$ & $S$ \\
\hline Kav 84 & Manisa & Unknown & $S$ & $\mathrm{R}$ & $\mathrm{H}$ & $S$ & $S$ \\
\hline Kav 85 & Nevsehir & Unknown & $\mathrm{R}$ & $S$ & $\mathrm{H}$ & $S$ & $S$ \\
\hline Kav 87 & Nigde & Unknown & $S$ & $\mathrm{R}$ & $S$ & $S$ & $S$ \\
\hline Kav 90 & Elazig & Unknown & $S$ & $\mathrm{R}$ & $S$ & $S$ & $S$ \\
\hline Kav 170 & Antalya & Unknown & $S$ & $S$ & $S$ & $S$ & $S$ \\
\hline Kav 191 & K.Maras & Unknown & - & - & $S$ & $S$ & $S$ \\
\hline Kav 213 & Ankara & Tirtilli & $S$ & $\mathrm{R}$ & $S$ & $S$ & $S$ \\
\hline Kav 214 & Ankara & Altınbas & $\mathrm{R}$ & $\mathrm{H}$ & $S$ & S & $S$ \\
\hline Kav 218 & Ankara & Ipsala & S & $\mathrm{H}$ & $S$ & S & $S$ \\
\hline Kav 221 & Ankara & Kislik & S & $\mathrm{R}$ & $S$ & S & $S$ \\
\hline Kav 226 & Ankara & Altin & $\mathrm{R}$ & $\mathrm{H}$ & $S$ & S & $S$ \\
\hline Kav 228 & Ankara & U.Yuva & S & $\mathrm{R}$ & $S$ & S & $S$ \\
\hline Kav 232 & Ankara & Cikolata & S & $\mathrm{H}$ & $S$ & S & $S$ \\
\hline Kav 234 & Ankara & Ipsala & $S$ & $S$ & $S$ & $S$ & $S$ \\
\hline Kav 235 & Ankara & Muhurlu & $S$ & $\mathrm{R}$ & $S$ & $S$ & $S$ \\
\hline Kav 237 & Ankara & Portakal & $S$ & $\mathrm{R}$ & $\mathrm{R}$ & $S$ & $S$ \\
\hline Kav 239 & Ankara & Dilimli & $S$ & $\mathrm{R}$ & $S$ & $S$ & $S$ \\
\hline Kav 242 & Ankara & Muz & $S$ & $\mathrm{R}$ & $S$ & $S$ & $S$ \\
\hline Kav 249 & Ankara & Kirkagac & $\mathrm{R}$ & $S$ & $S$ & $S$ & $S$ \\
\hline Kav 250 & Ankara & Sememe & $S$ & $\mathrm{R}$ & $S$ & $S$ & $S$ \\
\hline Kav 252 & Ankara & Tepekoy & $S$ & $\mathrm{R}$ & $\mathrm{H}$ & $S$ & $S$ \\
\hline Kav 255 & Konya & Kislik & S & $\mathrm{R}$ & $\mathrm{R}$ & - & $S$ \\
\hline Kav 265 & Erzurum & Unknown & $S$ & $\mathrm{R}$ & $S$ & $S$ & $S$ \\
\hline
\end{tabular}


Table 1. Continued.

\begin{tabular}{lccccccc}
\hline Genotype & Origin & Local name & $\begin{array}{c}\text { Fusarium } \\
\text { race 1 }\end{array}$ & $\begin{array}{c}\text { Fusarium } \\
\text { race 2 }\end{array}$ & $\begin{array}{c}\text { Downy } \\
\text { mildew }\end{array}$ & $\begin{array}{c}\text { Powdery } \\
\text { mildew }\end{array}$ & CMV \\
\hline Kav 266 & Erzurum & Unknown & $\mathrm{S}$ & $\mathrm{S}$ & $\mathrm{S}$ & $\mathrm{S}$ & $\mathrm{S}$ \\
Kav 267 & Erzurum & Unknown & $\mathrm{S}$ & $\mathrm{R}$ & $\mathrm{S}$ & $\mathrm{S}$ & $\mathrm{S}$ \\
Kav 269 & Erzurum & Unknown & $\mathrm{S}$ & $\mathrm{S}$ & $\mathrm{S}$ & $\mathrm{S}$ & $\mathrm{S}$ \\
Kav 273 & Erzurum & Unknown & $\mathrm{S}$ & $\mathrm{H}$ & $\mathrm{S}$ & $\mathrm{S}$ & $\mathrm{S}$ \\
Kav 274 & Erzurum & Unknown & $\mathrm{S}$ & $\mathrm{H}$ & $\mathrm{S}$ & $\mathrm{S}$ & $\mathrm{S}$ \\
Kav 277 & Erzurum & Unknown & $\mathrm{S}$ & $\mathrm{H}$ & $\mathrm{S}$ & $\mathrm{R}$ & $\mathrm{S}$ \\
Kav 278 & Erzurum & Unknown & $\mathrm{S}$ & $\mathrm{H}$ & $\mathrm{S}$ & $\mathrm{S}$ & $\mathrm{S}$ \\
Kav 279 & Erzurum & Unknown & $\mathrm{S}$ & $\mathrm{H}$ & $\mathrm{S}$ & $\mathrm{S}$ & $\mathrm{S}$ \\
Kav 280 & Erzurum & Unknown & $\mathrm{S}$ & $\mathrm{R}$ & $\mathrm{S}$ & $\mathrm{S}$ & $\mathrm{S}$ \\
Kav 281 & Elazig & Sari & $\mathrm{S}$ & $\mathrm{R}$ & $\mathrm{S}$ & - & $\mathrm{R}$ \\
Kav 282 & Elazig & Kis & $\mathrm{S}$ & $\mathrm{R}$ & $\mathrm{S}$ & $\mathrm{S}$ & $\mathrm{S}$ \\
Kav 284 & Elazig & Malbora & $\mathrm{H}$ & $\mathrm{H}$ & $\mathrm{S}$ & $\mathrm{S}$ & $\mathrm{S}$ \\
Kav 286 & Elazig & Muz & $\mathrm{S}$ & $\mathrm{R}$ & $\mathrm{S}$ & $\mathrm{S}$ & $\mathrm{S}$ \\
Kav 287 & Elazig & Kislik beyaz & - & - & $\mathrm{S}$ & $\mathrm{S}$ & $\mathrm{S}$ \\
Ac 1 & Ankara & Beyaz & $\mathrm{S}$ & $\mathrm{R}$ & $\mathrm{S}$ & $\mathrm{S}$ & $\mathrm{S}$ \\
Ac 3 & Ankara & Siyah & - & - & - & - & - \\
Ac5 & Sanliurfa & Hitta & $\mathrm{S}$ & $\mathrm{R}$ & $\mathrm{S}$ & $\mathrm{S}$ & $\mathrm{S}$ \\
Ac 14 & Mardin & Midyat 1 & - & - & $\mathrm{S}$ & $\mathrm{S}$ & - \\
Ac 16 & Adana & Adana & $\mathrm{S}$ & $\mathrm{R}$ & $\mathrm{S}$ & $\mathrm{S}$ & $\mathrm{S}$ \\
Ac 18 & K.Maras & Diyarbakır 2 & $\mathrm{S}$ & $\mathrm{R}$ & $\mathrm{S}$ & $\mathrm{S}$ & $\mathrm{S}$ \\
Ac 21 & K.Maras & Urfa & $\mathrm{S}$ & $\mathrm{R}$ & $\mathrm{S}$ & $\mathrm{S}$ & $\mathrm{S}$ \\
Ac 31 & AARI, Izmir & TR 40517 & $\mathrm{S}$ & $\mathrm{R}$ & $\mathrm{S}$ & $\mathrm{S}$ & $\mathrm{S}$ \\
Ac 32 & AARI, Izmir & TR 47782 & $\mathrm{S}$ & $\mathrm{R}$ & $\mathrm{S}$ & $\mathrm{S}$ & $\mathrm{S}$ \\
Ac 33 & AARI, Izmir & TR 47808 & $\mathrm{S}$ & $\mathrm{R}$ & $\mathrm{S}$ & $\mathrm{S}$ & $\mathrm{R}$ \\
Ac 47 & AARI, Izmir & TR 51559 & $\mathrm{S}$ & $\mathrm{R}$ & $\mathrm{S}$ & $\mathrm{S}$ & $\mathrm{S}$ \\
Ac 51 & Sanliurfa & Hitta & $\mathrm{S}$ & $\mathrm{R}$ & $\mathrm{S}$ & $\mathrm{S}$ & $\mathrm{S}$ \\
Ac54 & Siirt & Unknown & $\mathrm{S}$ & - & $\mathrm{S}$ & $\mathrm{S}$ & $\mathrm{S}$ \\
Ac 56 & Nigde & Unknown & $\mathrm{S}$ & $\mathrm{R}$ & $\mathrm{S}$ & $\mathrm{S}$ & $\mathrm{S}$ \\
Ac 60 & Sanliurfa & Tuylu & $\mathrm{S}$ & $\mathrm{R}$ & $\mathrm{S}$ & $\mathrm{S}$ & - \\
\hline
\end{tabular}

$\mathrm{S}$, Susceptible, $\mathrm{R}$, resistant, $\mathrm{H}$, heterogeneous. -, No germination.

Fusarium wilt, downy mildew, powdery mildew, CMV and ZYMV tests were conducted at INRA, Avignon, France. All tests were performed using the protocol of Pitrat et al. (1991). Ten plants for fungal diseases and 15 plants for virus diseases were used.

All genotypes were tested for $F$. oxysporum races 1 and 2 . 'Charentais Fom- 1 ' (susceptible to race 1 and resistant to race 2) and 'Charentais Fom-2' (resistant to race 1, susceptible to race 2) were used as controls. Inoculation was done by a root dipping method. Spores of downy mildew were produced on the susceptible line 'Védrantais' and used to inoculate five leaf discs per accession. 'Védrantais' was used as a susceptible control and 'PI 124112' and 'MR1' as resistant controls. For powdery mildew screening, a strain of race 3 of $P$. xanthii was used and increased on bottle gourd (Lagenaria) cotyledons. Five leaf discs of each accession were inoculated. The susceptible controls were 'Védrantais' and 'PMR 45', and 'RIL 56' ('Védrantais' × 'PI 124112') as a resistant control (Perchepied et al., 2005). CMV and ZYMV were tested as virus diseases. 'Védrantais' was the susceptible control for both viruses, while the resistant controls were 'Virgos' for CMV and 'PI 414723' for ZYMV.

\section{RESULTS AND DISCUSSION}

A core collection of 100 melon and snake melon genotypes collected from different regions of Turkey (middle Anatolia, Aegean, Mediterranean, eastern Anatolia, south-eastern 
Anatolia and Marmara-Thrace) and obtained from the National Gene Bank of Turkey (AARI) was tested for Fusarium wilt, downy mildew, powdery mildew, CMV and ZYMV at INRA, Avignon, France. The results are presented in Table 1.

In the case of Fusarium wilt race 1, 8 accessions ('Kav 29', 'Kav 36', 'Kav 57', 'Kav 71', 'Kav 85', 'Kav 214', 'Kav 226' and 'Kav 249') were found to be resistant, while the others were susceptible. Segregation was observed only in 'Kav 284'. It is worth noting that the geographical origins of the resistant genotypes were not the same. Moreover, the wild genotype 'Kav 71', belonging to C. melo group agrestis, was identified as resistant, while the other wild genotype 'Kav 73' was found to be susceptible. Regarding Fusarium wilt race 2, 51 accessions were resistant and 26 were susceptible, while 17 genotypes showed segregation. As for race 1, geographical origins were not correlated with resistance/susceptibility. While C. melo group agrestis genotypes ('Kav 63' and 'Kav 71') were identified as susceptible, C. melo group dudaim genotypes ('Kav 64' and 'Kav 250') were found to be resistant.

F. oxysporum f. sp. melonis is an economically destructive soil-borne disease agent, and four races (0,1, 2 and 1-2) have been defined (Risser et al., 1976; Pitrat et al., 1991). The most widespread races are 0 and 1 in Turkey (Sari et al., 1994), race 1-2 were observed in the Aegean region (Yildiz, 1977) and in the east Mediterranean region (Yucel et al., 1994); however, all four races were detected in middle Anatolia (Erzurum et al., 1999). Our results are in agreement with the report of Sensoy et al. (2007), who tested 79 melon accessions with fusarium wilt race 1 and found only seven resistant genotypes, three genotypes as heterogeneous and the rest as susceptible. In another study performed by Pitrat et al. (1996), 271 melon genotypes from around the world were tested for $F$. oxysporum f.sp. melonis race 1,2 and $1-2$ with $20 \%$ of the genotypes found to be susceptible to all three races. In their study of 271 accessions, resistance to race 2 was $14.7 \%$ (22.4\% including the heterogeneous accessions) and $13.8 \%$ for race 1 ( $22 \%$ including the heterogeneous accessions), while only $3 \%$ were found to be resistant to race $1-2$.

Regarding downy mildew, four genotypes ('Kav 28', 'Kav 71', 'Kav 237' and 'Kav 255') were observed as resistant, 16 were heterogeneous and the other genotypes were susceptible. The four genotypes constitute new sources of resistance to downy mildew, which have so far been found mainly in Indian accessions, such as 'PI 124112' and 'MR1' (Thomas and Jourdain, 1992; Dhillon et al., 2007).

Powdery mildew (P. xanthii) is one of the first determined fungal diseases of melon (Pitrat et al., 1998), which is damaging both in open fields and under greenhouse conditions. Among the Turkish melon and snake melon genotypes, only 'Kav 60' and 'Kav 277' (which were collected from the North Cyprus Turkish Republic and Erzurum, respectively) were observed as resistant to race 3. As for downy mildew, most known resistances to powdery mildew originate from India (Pitrat et al., 1996), and so our work may have identified valuable new sources of resistance to this disease.

CMV was the first viral disease identified in cucurbits (Doolittle, 1916; Jagger, 1916), and has the widest host range of any plant virus, including more than 1200 species in over 100 families. In this study, two genotypes ('Kav 281' and 'Ac 33') were determined as resistant, while the others were susceptible. This is an interesting result as, to date, high levels of resistance to CMV have mainly been reported only in melons from the Far East (Dogimont, 2011). Gómez-Guillamón et al. (1998) evaluated landraces and wild varieties and reported that none of them were resistant to CMV. Among 36 snapmelon landraces $(C$. melo var. momordica) collected in India, a single one was found resistant to CMV (Dhillon et al., 2007).

ZYMV is an important pathogen in cucurbit-growing regions throughout the world (Antignus et al., 1989; Lecoq and Desbiez, 2012). In our collection, all the genotypes were found to be susceptible to ZYMV. This result is consistent with the fact that resistance to ZYMV is found with a very low frequency in melon, such as the study of more than 500 accessions by Pitrat et al. (1996), in which only a single accession, 'PI 414723', showed resistance. 


\section{CONCLUSIONS}

In this study, we tested 85 melon and 15 snake melon accessions for Fusarium wilt, downy mildew, powdery mildew, CMV and ZYMV. Although these accessions represent only a small proportion of Turkish melon germplasm, potential new sources of resistance have been identified. This valuable genetic material must be conserved for the future, and more emphasis given to using these resistant genotypes in future breeding studies.

\section{ACKNOWLEDGEMENTS}

The authors are grateful to the Turkish Scientific and Technological Council for financial support (project no. TUBITAK BOSPHORUS 107T616); National Gene Bank of Turkey, Turkey Atomic Research Institute, Alata Horticultural Research Station and Assoc. Prof. Dr. Ertan Yildirim for the seed supplies and Nathalie Giovinazzo for her technical assistance during disease tests.

\section{Literature cited}

Antignus, Y., Raccah, B., Gal-On, A., and Cohen, S. (1989). Biological and serological characterization of zucchini yellow mosaic virus and watermelon mosaic virus-2 isolates in Israel. Phytoparasitica 17 (4), 289298 http://dx.doi.org/10.1007/BF02980758.

Baran, B. (2000). Guneydogu Anadolu bolgesi kavun ekim alanlarinda solgunluk hastaligi etmeni "Fusarium oxysporum f.sp. melonis (Leach and Currence)" in yayginligi ve bu etmene karsi bazi kavun cesitlerinin tepkileri. YYÜ Fen Bil. Ens. Yuksek Lisans Tezi (Van), pp.29.

Demir, S., and Tezcan, H. (1995). Van ili kavunlarinda toprak kaynakli funguslarin neden oldugu kurumalar uzerinde arastirmalar. Paper presented at: VII Türkiye Fitopatoloji Kongresi (Adana, Turkey), pp.204-207.

Dhillon, N.P.S., Ranjana, R., Singh, K., Eduardo, I., Monforte, A.J., Pitrat, M., Dhillon, N.K., and Singh, P.P. (2007). Diversity among landraces of Indian snapmelon (Cucumis melo var. momordica). Genet. Resour. Crop Evol. 54 (6), 1267-1283 http://dx.doi.org/10.1007/s10722-006-9108-2.

Dogimont, C. (2011). 2011. Gene list for melon. Rep. Cucurbit Genet. Coop. 33/34, 104-113.

Doolittle, S.P. (1916). A new infectious mosaic disease of cucumber. Phytopathology 6, 145-147.

Erzurum, K., Taner, Y., Secer, E., Yanmaz, R., and Maden, S. (1999). Occurrence of races of Fusarium oxysporum f.sp. melonis causing wilt on melon in Central Anatolia. J. Turk. Phytopathol. 28, 87-97.

FAO. (2012). http://faostat.fao.org.

Gómez-Guillamón, M.L., Moriones, E., Luís-Arteaga, M., Alvarez, J.M., Torés, J.A., LópezSesé, A.I., Cánovas, I., Sánchez, F., and Camero, R. (1998). Morphological and disease resistances evaluation in Cucumis melo and its wild relatives. In Cucurbitaceae '98 Evaluation and Enhancement of Cucurbits Germplasm, J.D. McCreight, ed. (Alexandria, VA, USA: ASHS Press), p.53-61.

Jagger, I.C. (1916). Experiments with the cucumber mosaic disease. Phytopathology 6, 148-151.

Kinay, P., Yıldız, M., and Buanoglu, M. (1995). Ege Bolgesinde kavun kurumalari ve patojenik mikrofloranin sulamayla iliskisi. Paper presented at: VII Turkiye Fitopatoloji Kongresi (Adana, Turkey), p.191-194.

Kirkbride, J.H. (1993). Biosystematic Monograph of the Genus Cucumis (Cucurbitaceae) (Boone, NC, USA: Parkway Publishers).

Koc, K. (1986). Sebze Hastaliklari. C.Ü. Ziraat Fakultesi, Ders Notu Yay., No. 136 (Adana, Turkey).

Kurt, S., Baran, B., Sari, N., and Yetisir, H. (2002). Physiologic races of Fusarium oxysporum f.sp. melonis in the Southeastern Anatolia region of Turkey and varietal reactions to races of the pathogen. Phytoparasitica 30 (4), 395-402 http://dx.doi.org/10.1007/BF02979687.

Lebeda, A., and Cohen, Y. (2011). Cucurbit downy mildew (Pseudoperonospora cubensis) - biology, ecology, epidemiology, host-pathogen interaction and control. Eur. J. Plant Pathol. 129 (2), 157192 http://dx.doi.org/10.1007/s10658-010-9658-1.

Lecoq, H., and Desbiez, C. (2012). Viruses of cucurbit crops in the Mediterranean region: an ever-changing picture. In Viruses and Virus Diseases of Vegetables in the Mediterranean Basin, G. Loebenstein and H. Lecoq, eds. (Amsterdam, Netherlands: Elsevier). p.67-126.

Maden, S., Erzurum, K., Yanmaz, R. and Taner, K.Y. (1998). Orta Anadolu bolgesinde kavun solgunluk etmeni Fusarium oxysporum f.sp. melonis'in irklarinin belirlenmesi. TUBITAK/TOGTAG/1585 No'lu Proje Kesin Raporu, pp.14. 
Martyn, R.D., and Gordon, T.R. (1996). Fusarium wilt of melon. In Compendium of Cucurbit Diseases, T.A. Zitter, D.L. Hopkins, and C.D. Thomas, eds. (St. Paul, MN, USA: American Phytopathological Society), p.14-15.

Özgen, M., Adak, M.S., Soylemezoglu, G., and Ulukan, H. (2000). Bitkisel gen kaynaklarinin korunma ve kullaniminda yeni yaklasimlar. Paper presented at: V. Türkiye Ziraat Mühendisligi Teknik Kongresi (Ankara, Turkey).

Perchepied, L., Bardin, M., Dogimont, C., and Pitrat, M. (2005). Relationship between Loci conferring downy mildew and powdery mildew resistance in melon assessed by quantitative trait Loci mapping. Phytopathology 95 (5), 556-565 http://dx.doi.org/10.1094/PHYTO-95-0556. PubMed

Pitrat, M., Risser, G., Epinat, C., Ferriere, C., Ricard, M., Olivier, C., Ruffinato, A., Lecoq, H., Blancard, D., Bertnard, F., et al. (1991). Techniques d'inoculation artificielle du melon avec différents agents pathogènes pour la sélection de variétés résistantes. INRA Domaine Saint Maurice BP 94, 84143.

Pitrat, M., Risser, G., Bertrand, F., Blancard, D., and Lecoq, H. (1996). Evaluation of a melon collection for disease resistances. Paper presented at: VIth Eucarpia Meeting on Cucurbit Genetics and Breeding (Malaga, Spain).

Pitrat, M., Dogimont, C., and Bardin, M. (1998). Resistance to fungal diseases of foliage in melon. In Cucurbitaceae '98, Evaluation and Enhancement of Cucurbit Germplasm, J.D. McCreight, ed. (Alexandria, VA, USA: ASHS Press), p.167-173.

Pitrat, M., Hanelt, P., and Hammer, K. (2000). Some comments on infraspecific classification of cultivars of melon. Acta Hortic. 510, 29-36 http://dx.doi.org/10.17660/ActaHortic.2000.510.4.

Polat, İ., Baysal, Ö., Mercati, F., Kitner, M., Cohen, Y., Lebeda, A., and Carimi, F. (2014). Characterization of Pseudoperonospora cubensis isolates from Europe and Asia using ISSR and SRAP molecular markers. Eur. J. Plant Pathol. 139 (3), 641-653 http://dx.doi.org/10.1007/s10658-014-0420-y.

Risser, G., Banihashemi, Z., and Davis, D.W. (1976). A proposed nomenclature of Fusarium oxysporum f. sp. melonis races and resistance genes in Cucumis melo. Phytopathology 66 (9), 11051106 http://dx.doi.org/10.1094/Phyto-66-1105.

Sari, N., and Solmaz, I. (2007). Fruit characterization of some Turkish melon genotypes. Acta Hortic. 731, 103109 http://dx.doi.org/10.17660/ActaHortic.2007.731.14.

Sari, N., Pitrat, M., Abak, K. and Yucel, S. (1994). Türkiye'de yaygn olarak yetistirilen karpuz ve kavun cesitlerinin bazi fungal hastaliklara ve viruslere karsi reaksiyonları. Ç.U. Ziraat Fakultesi, 25. Kuruluş Yılı Ozel Sayısı, p.37-50.

Scherf, A.F., and Mancab, A. (1986). Vegetable Diseases and Their Control, $2^{\text {nd }}$ edn (New York, NY, USA: WileyInterscience).

Sensoy, S., Demir, S., Buyukalaca, S., and Abak, K. (2007). Response of Turkish melon genotypes to Fusarium oxysporum f. sp. Race 1 determined by inoculation tests and RAPD Markers. Eur. J. Hortic. Sci. 72, 220-227.

Solmaz, I., Aras, V., Unlu, H., and Sari, N. (2004). Characterization of snake melon (Cucumis melo var. flexuosus) genotypes which are collected from the different regions of Turkey. Paper presented at: Turkey $5^{\text {th }}$ National Vegetable Production Symposium (Canakkale, Turkey: Canakkale Onsekiz Mart University, Faculty of Agriculture).

Thomas, C.E., and Jourdain, E.L. (1992). Evaluation of melon germplasm for resistance to downy mildew. HortScience 27, 434-436.

Whitaker, T.W., and Davis, G.N. (1962). Cucurbits: Botany, Cultivation and Utilization (New York, NY, USA: Interscience).

Yildiz, M. (1977). Ege bölgesinde kavun solgunluk etmeninin patojenitesi, irkları ve yerel cesitlerin dayanikliginin saptanmasi uzerinde arastirmalar. E.U. Ziraat Fakultesi Bitki Koruma Bolumu, Docentlik Tezi, pp.112.

Yilmaz, M.A., and Davis, R.F. (1984). Purification and particule morphology of TMV, CMV and ZYMV isolated from various cultivated crops grown along the Mediterranean coast of Turkey. J. Turk. Phytopathol. 13, 29-38.

Yilmaz, M.A., and Davis, R.F. (1985). Identification of viruses infecting vegetable crops along the Mediterranean Sea coast in Turkey. J. Turk. Phytopathol. 14, 1-8.

Yucel, S., Pala, H., Sari, N., and Abak, K. (1994). Determination of Fusarium oxysporum f.sp. melonis races in the east Mediterranean region of Turkey and response of some melon genotypes to the disease. Paper presented at: $9^{\text {th }}$ Congress of the Mediterranean Phytopathological Union, (Kusadası-Aydın, Turkey).

Zengin, H., Yildirim, G. and Gulsoy, E. (1975). Marmara bolgesinde kavunda Fusarium oxysporum f.sp.melonis, karpuzda Fusarium oxysporum f.sp. niveum solgunluk etmeni ve kimyasal savas olanaklari uzerinde arastirmalar. Erenköy Böl. Zir. Muc. Arast. Enst. E-108-829 No’lu Proje Nihai Raporu. 
